\title{
能登半島北端の新生界から産出する特異な形態の 珪質コンクリーション
}

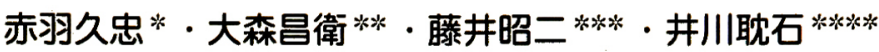

\begin{abstract}
Hisatada Akahane*, Masae Ohmori**, Shoji Fujii ${ }^{* * *}$ and Chinseki Igawa**** : Siliceous concretions of peculiar form occurred from the Cenozoic formation in the Northern Part of Noto Peninsula, Ishikawa Prefecture, Central Japan
\end{abstract}

1998年11月 11 日受付. 2000 年 6 月 19 日受理.

*富山市科学文化センター Toyama Science Museum, 939-8084, Japan ${ }^{* *}$ 元麻布大学 Ex. Azabu University, 229-8501, Japan *** 藤井環境地質研究所 Fujii Laboratory for Geological Environments, 939-8075, Japan **** 子ぶり石愛好会 Koburiishi Fun Club, 927-1467, Japan

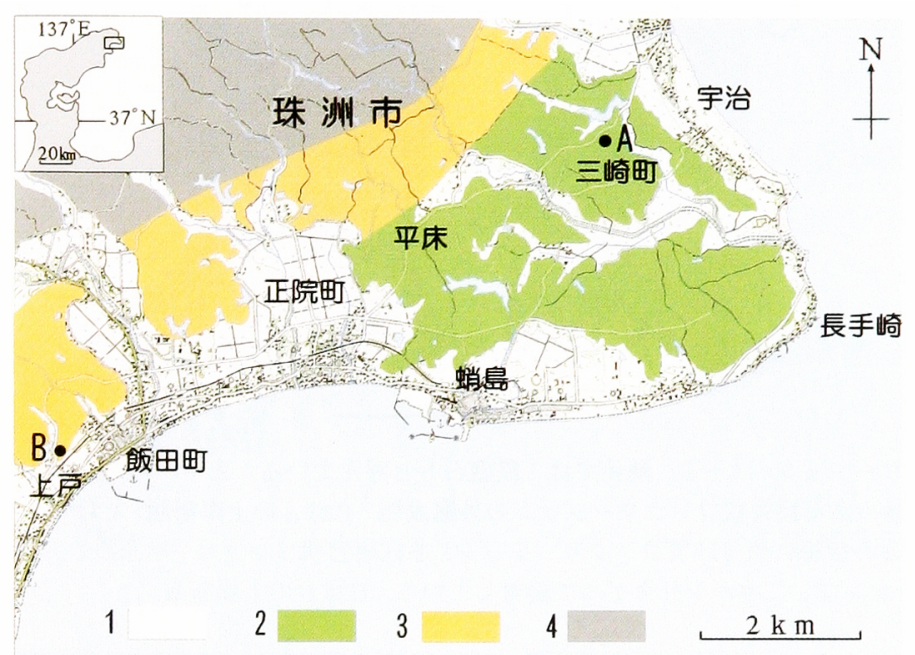

第 1 図．海崖段丘区分図に打ける理質コンクリーション(「子ぶり石」と 「鉄佨石」）を産出する地点（A）と段丘基盤の饭塚理潈泥岩中に理質コンク リーションの発達している露頍の地点 $($ B $) .1$ : 沖䅡層, 2 : 游抜約 $30 \mathrm{~m}$ の 段丘（平床面 $5 \mathrm{e}$ )，3：海抜約 $40 \mathrm{~m}$ の段丘，4：海抜絢 $55 \mathrm{~m}$ 以上の段丘扣よ

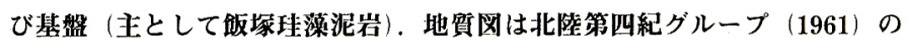
一部を改変したもの. 国土地理院発行 $1 / 5$ 万地形图「能登饭田」使用.

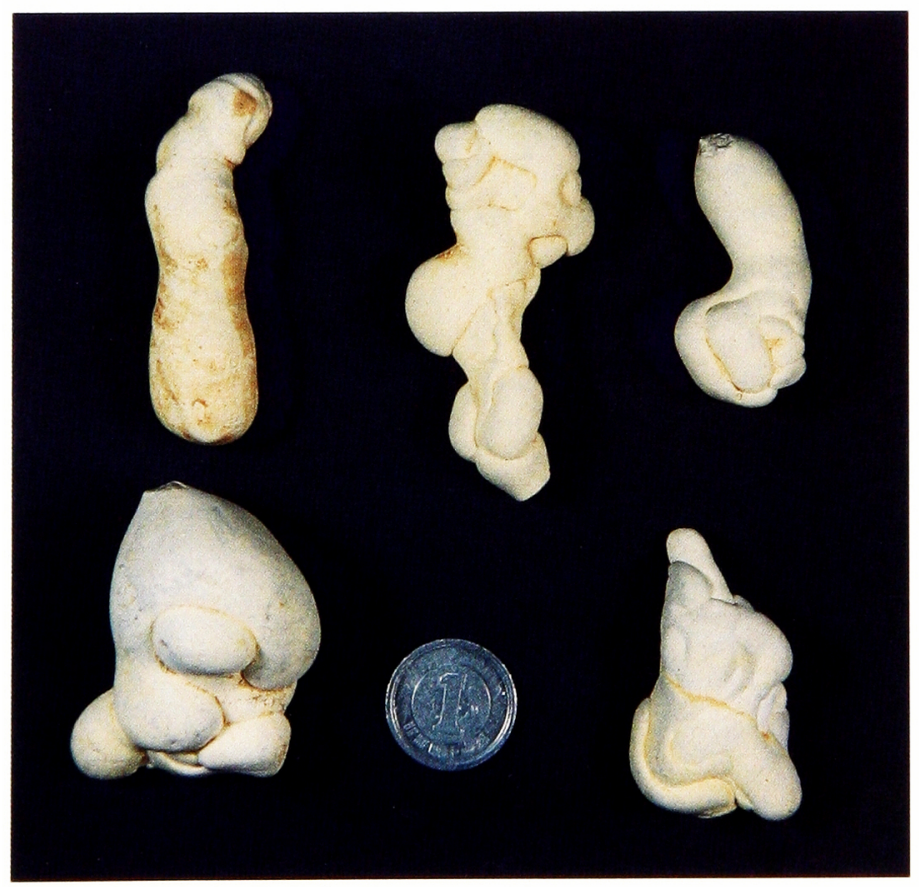

能登半島北端部の珠洲市三崎の段丘堆積物（第1図, A) から，子ふり石・仏石・箁薩石などと呼ばれる特異な形態 の珪質コンクリーションが産出する (第2図)。これらに は直径は $5 \mathrm{~mm} \sim 50 \mathrm{~mm}$, 長さ $10 \mathrm{~cm}$ を超える大小さまざ まな珪質の棲管状コンクリーションを伴っており，鉄砲石 と呼ばれている (第3図 $\mathrm{A} \sim \mathrm{F})$. 産出地点の段丘は中新統 飯塚珪藻泥岩層を基盤とする平床面 $5 \mathrm{e}$ （約 12 万年前）に 属し，珪質コンクリーションは基盤に由来すると考えられ るが，この地点では確認できていない.

一方，珠洲市の土石採集現場（第1図，B）の飯塚珪藻 泥岩層で, 多数の珪質コンクリーションが観察された（第 4 図A，B）。この事実は珠洲市三崎の段丘堆積物から産出 する珪質コンクリーションが飯塚珪藻泥岩層から洗い出さ れた二次堆積物である可能性が極めて高いことを示してい る.上戸の露頭では棲管状コンクリーションの産出を確認 できなかったが，子ぶり石と棲管状コンクリーションが段 丘堆積物中で共産する事実を重視すると, 三崎の段丘堆積 物中の棲管状コンクリーションもまた基盤の飯塚珪藻泥岩 層から由来したものと考えられる.

英国の白亜系チョーク中には，生痕化石を起源とするフ リント（第3図 G，H）の産出が知られている（Bromley and Ekdale, 1986）が，それらの一部の産状と形態は（第5 図A，B）飯塚珪藻泥岩層から産出するコンクリーション の産状（第4図A，B）と非常によく似ている．珪藻泥岩 やチョーク中における珪質コンクリーションやフリントの 形成時期・メカニズムは極めて興味深い。

\section{文献}

Bromley, R. G. and Ekdale, A.A., 1986, Flint and fabric in the European chalk. The scientific study of flint and chert. Proc. of the 4th Int'l Flint Symp, held at Brighton Polytech, 10-15 April 1983, 71-82.

北陸第四紀研究グループ, 1961, 能登半島平床台地の第四系. 地 球科学, 54, 1-19.

付記：本報告の共著者の一人井川耽石氏（子ぶり石愛好会会長） が去る6月7日，現地調査中に急逝された。謹んで哀悼の 意を表します。

第 2 図. 珠洲市三崎町（第 1 图A）から産出する理質コンクリーシ ヨン. 地元では形热の特徵によって「子ぶり石」「仏石」「菩萨石」 などと呼んでいる，スケールは1冈硬貨. 

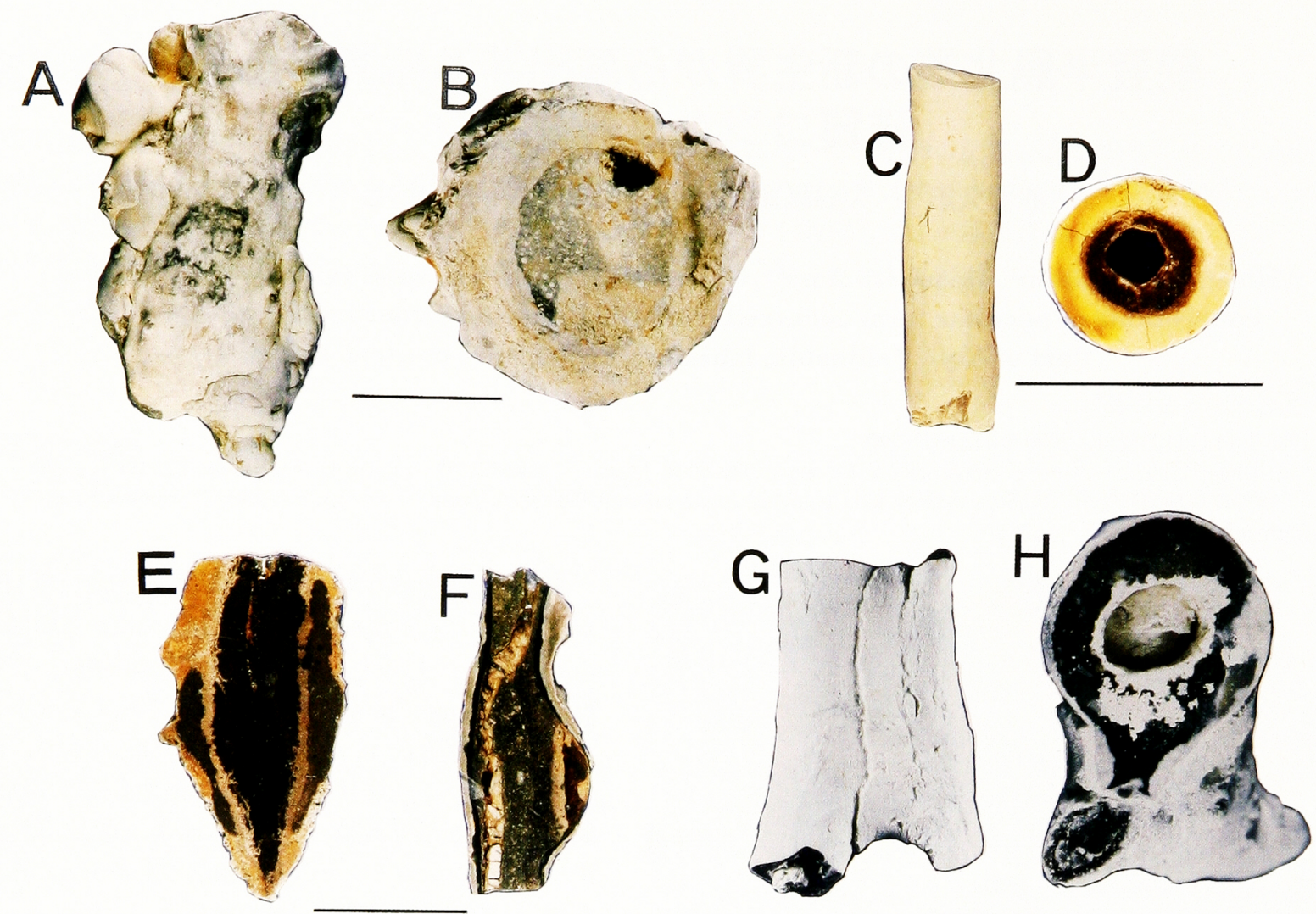

第3図．珠洲市三崎町（第1图A）から産出した珪質楼管状コンクリーション（AＦ．地元では「鉄佨石」と呼んでいる）とドーバーの

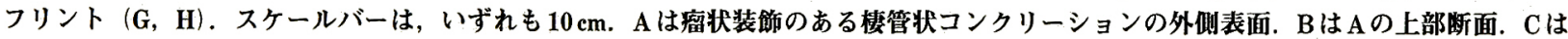
中空の棲管状コンクリーション. D はCC上部断面. E は Rosseliaの棲管に似る理質コンクリーション． F は棲管状コンクリーション. Gはドーバー地方でフリントと共産する理質の楼管状コンクリーションで，二本がシリカゲルで檤着している．HはGの上部断面.
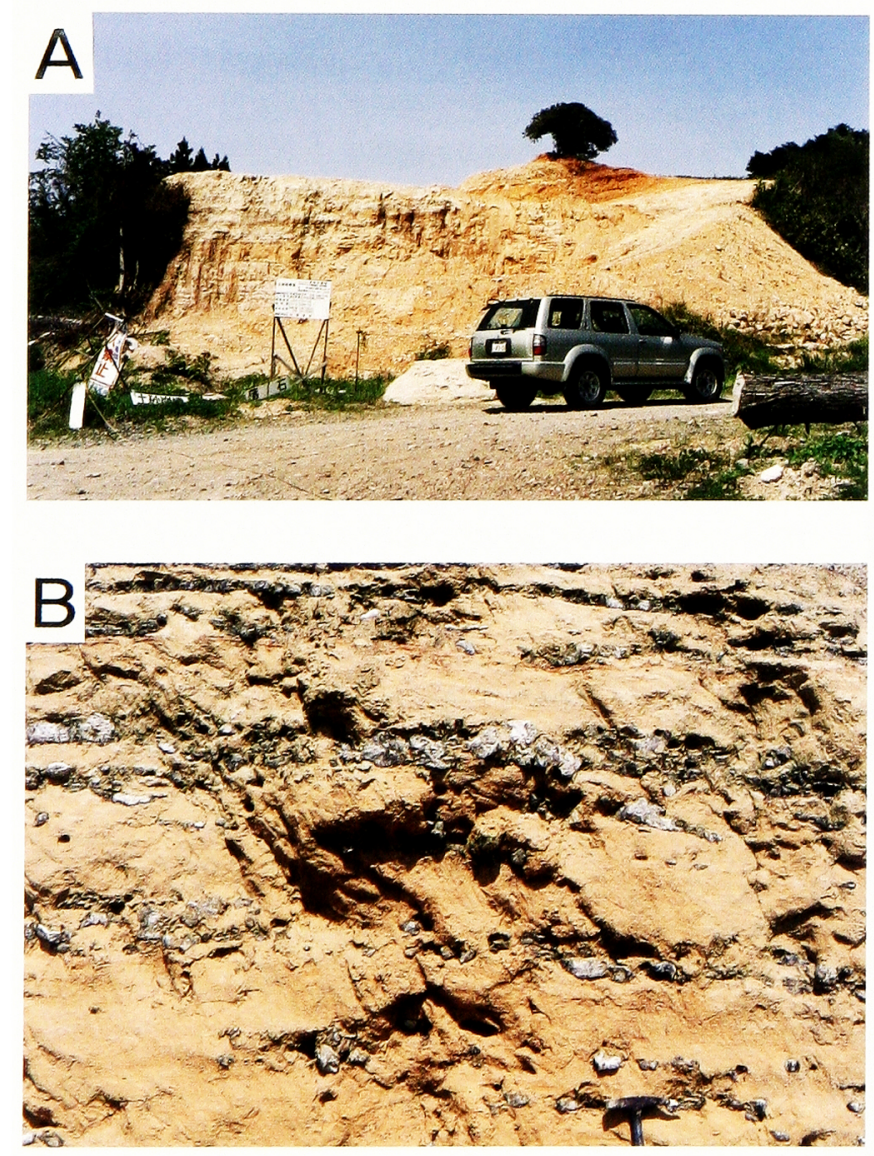

第4图，第1图Bの土石採集現場（A）における理質コンクリーショ ンの産状 (B) 。
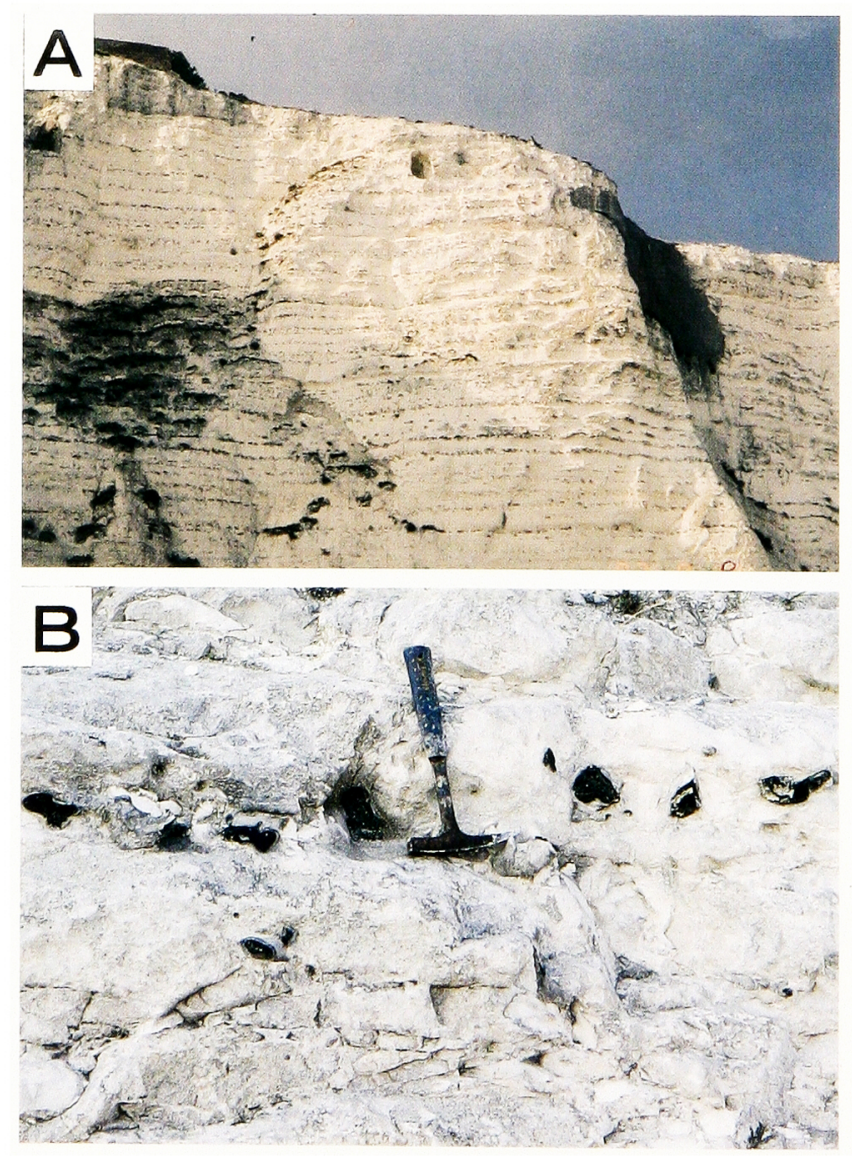

第5図. ドーバー (英国) のチョークの崖（A）に見られる破而が 黑色をしたフリントの産状（B）. 